\title{
Isolation of a yeast strain able to produce a polygalacturonase with maceration activity of cassava roots \\ María Alicia MARTOS ${ }^{1 \star}$, Emilce Roxana ZUBRESKI ${ }^{1}$, Mariana COMBINA², Oscar Alfredo GARRO ${ }^{3}$, Roque Alberto HOURS ${ }^{4}$
}

\begin{abstract}
The objective of the present study was the isolation of a yeast strain, from citrus fruit peels, able to produce a polygalacturonase by submerged fermentation with maceration activity of raw cassava roots. Among 160 yeast strains isolated from citrus peels, one strain exhibited the strongest pectinolytic activity. This yeast was identified as Wickerhamomyces anomalus by 5.8S-ITS RFLP analysis and confirmed by amplification of the nucleotide sequence. The yeast produced a polygalacturonase (PG) in Erlenmeyer shake flasks containing YNB, glucose, and citrus pectin. PG synthesis occurred during exponential growth phase, reaching 51 UE.mL $\mathrm{mL}^{-1}$ after 8 hours of fermentation. A growth yield $\left(\mathrm{Y}_{\mathrm{x} / \mathrm{s}}\right)$ of 0.43 gram of cell dry weight per gram of glucose consumed was obtained, and a maximal specific growth rate $\left(\mu_{\mathrm{m}}\right)$ of $0.346 \mathrm{~h}^{-1}$ was calculated. The microorganism was unable to assimilate sucrose, galacturonic acid, polygalacturonic acid, or citrus pectin, but it required glucose as carbon and energy source and polygalacturonic acid or citrus pectin as inducers of enzyme synthesis. The crude enzymatic extract of Wickerhamomyces anomalus showed macerating activity of raw cassava. This property is very important in the production of dehydrated mashed cassava, a product of regional interest in the province of Misiones, Argentina.
\end{abstract}

Keywords: Wickerhamomyces anomalus; polygalacturonase; maceration; cassava.

\section{Introduction}

Pectinases are responsible for the degradation of pectic substances that occur as structural polysaccharides in the middle lamella and the primary cell walls of plant tissues. Based on their mode of action, these enzymes include polygalacturonase $(\mathrm{PG})$, pectin lyase $(\mathrm{PL})$, pectate lyase $(\mathrm{PAL})$, and pectin esterase (PE). PG, PL, and PAL are depolymerizing enzymes which split the $\alpha-(1,4)$-glycosidic bonds between galacturonic monomers in pectic substances, either by hydrolysis (PG) or by $\beta$-elimination (PL, PAL). PG catalyses the hydrolytic cleavage of the polygalacturonic acid chain, while PL performs a transeliminative split of pectin molecule producing an unsaturated product. PE catalyes the de-esterification of the methoxyl group of pectin forming pectic acid. (JAYANI; SAXENA; GUPTA, 2005; TARI; GÖGUS; TOKATLI, 2007). Pectinases play an important role in food technology, mainly in the processing of fruit juices and wines and in the maceration of plant tissue.

Maceration is a process by which an organized tissue is transformed into a suspension of intact cells by the action of pectinases resulting in pulpy products used to prepare baby and geriatric foods. For such purposes, only the intercellular cementing material that holds together cells (protopectin) and some portions of primary plant cell walls should be removed without damage to adjacent secondary cell walls, to help avoid cell lysis, keeping nutritional properties of food (COSTA et al., 2007).

Dehydrated mashed cassava is a product made from the cassava root (Manihot esculenta Crantz) using a technological process in the province of Misiones, Argentina. It can be used as a food item or as feedstock for the production of pasta or pasta mixtures. Its production is currently performed by drying and milling methods which produce a large cellular disruption (BROUSSE et al., 2012). The cassava tissue maceration, by enzymatic methods, constitutes an alternative for the production of dehydrated mashed cassava; this method would improve not only the functional but also the nutritional properties of the product.

Pectinases used in the food industry are commercially produced by Aspergillus niger. Yeasts have advantages compared to filamentous fungi with regards to the production of pectinases because they are unicellular, and their growth is relatively simple in economical culture media and relatively easier to perform at larger scale (DA SILVA et al., 2005).

The objective of the present study was the isolation of a yeast strain able to produce a polygalacturonase by submerged fermentation with maceration activity of raw cassava tissues. This enzyme could be tentatively used in the production of

\footnotetext{
Received 11/9/2012

Accepted 7/3/2013 (005877)

Facultad de Ciencias Exactas, Químicas y Naturales, Universidad Nacional de Misiones, Felix de Azara, 1552, CP 3300, Posadas, Misiones, Argentina,

e-mail: amartos@fceqyn.unam.edu.ar

2 Instituto Nacional de Tecnología Agropecuaria - INTA, EEA Mendoza, San Martín, 3853, CP 5507, Luján de Cuyo, Mendoza, Argentina

${ }^{3}$ Universidad Nacional del Chaco Austral, Comandante Fernández, 755, CP 3700, Presidencia Roque Sáenz Peña, Chaco, Argentina

${ }^{4}$ Centro de Investigación y Desarrollo en Fermentaciones Industriales - CINDEFI, CONICET La Plata, Facultad de Ciencias Exactas,

Universidad Nacional de la Plata - UNLP, Calle, 47 y 115, CP 1900, La Plata, Argentina

${ }^{*}$ Corresponding author
}

DOI: http://dx.doi.org/10.1590/S0101-20612013005000047 
dehydrated mashed cassava, a product of regional economic interest in the province of Misiones, Argentina.

\section{Materials and methods}

\subsection{Culture media}

Enrichment broth: yeast extract (Sigma Chemical Co., St. Louis, Mo, USA), 5 g.L L $^{-1}$; tryptone (Difco-Becton Dickinson), 5 g. $\mathrm{L}^{-1}$; glucose (Britania, Buenos Aires, Argentina), 10 g. $\mathrm{L}^{-1}$; calcium propionate, 1.3 g.L. $\mathrm{L}^{-1}$; oxytetracycline (Pfizer, Buenos Aires, Argentina), and $100 \mathrm{mg} . \mathrm{L}^{-1} ; \mathrm{pH}: 5.0$.

Isolation medium: this medium has the same composition of that of enrichment broth but with the addition of agar (Britania), 15 g. $\mathrm{L}^{-1}$.

YM: yeast extract (Sigma), 5 g.L $\mathrm{L}^{-1}$; tryptone (Difco), 5 g.L. $\mathrm{L}^{-1}$; glucose (Britania), 10 g.L. ${ }^{-1}$; agar (Britania), 15 g.. $\mathrm{L}^{-1}$; and pH: 5.0.

YNB agar: Yeast Nitrogen Base (YNB, Difco), 6.7 g.L.' polygalacturonic acid (PGA, Sigma), 5 g. $\mathrm{L}^{-1}$; glucose (Britania), 5 g.L ${ }^{-1}$; agar (Britania), 15 g.L.- ; and pH: 5.0.

YNB broth: YNB (Difco), 6.7 g.L.-1; glucose (GLU, Britania), sucrose (SUC, Britania), galacturonic acid (GA, Sigma), polygalacturonic acid (Sigma) or citrus pectin (PEC, Parafarm, Buenos Aires, Argentina), 5 g.L $\mathrm{L}^{-1}$.

Citrus pectin was washed with a $70 \%(\mathrm{v} / \mathrm{v})$ ethanol- $\mathrm{HCl}$ $(0.05 \mathrm{~N})$ solution to remove soluble sugars.

All media components were autoclaved $\left(121^{\circ} \mathrm{C}, 15\right.$ minutes $)$, except in the case of YNB solution, which was sterilized separately by filtration through a cellulose filter paper $(0.22 \mu \mathrm{m}$, Sartorius).

\subsection{Isolation of pectinolytic yeast}

Citrus fruit peels (10 g) were placed in flasks containing sterile $0.1 \%(\mathrm{w} / \mathrm{v})$ peptone water. The homogenate $(1 \mathrm{~mL})$ was loaded in $10 \mathrm{~mL}$ of enrichment broth and incubated at $30^{\circ} \mathrm{C}$ for 48 hours. An aliquot of the culture was serially diluted, plated in isolation medium, and incubated at $30^{\circ} \mathrm{C}$ for $24-48$ hours. The yeasts isolated were maintained at $4^{\circ} \mathrm{C}$ on YM medium slopes.

\subsection{Screening of yeasts for pectinase production}

Yeasts isolated were cultured in Petri dishes containing YNB agar. The Petri dishes were incubated at $30{ }^{\circ} \mathrm{C}$ for 3 days and then flooded with $5 \mathrm{~N} \mathrm{HCl}$. Pectinolytic activity was indicated by the formation of a clear halo around the colonies (SCHWAN; COOPER; WHEALS, 1997; DA SILVA et al., 2005).

\subsection{Identification of yeast}

Yeast isolated was submitted to molecular identification. DNA extraction was carried out according to Hoffman and Winston (1987).

The region between the $18 \mathrm{~S}$ rRNA and 28S rRNA genes (5.8S-ITS) was amplified using specific internal transcribed spacers ITS1 (5'-TCCGTAGGTGAACCTGCGG-3') and ITS4
(5'-TCCTCCGCTTATTGATATGC-3'), primers (WHITE et al., 1990). To achieve greater polymorphism, the amplified genes were treated with the restriction enzymes CfoI, Hinfl, and HaeIII for the identification of yeasts at the species level (ESTEVE ZARZOSO et al., 1999; GRANCHI et al., 1999). The PCR amplified 5.8S ITS rRNA region was sequenced using the ABI Prism 3100 genetic analyzer. The sequence comparisons were performed using the Basic Local Alignment Search Tool (BLAST) available from NCBI database (ALTSCHUL et al., 1990).

\subsection{Production of pectinolytic enzymes in submerged fermentation}

Five hundred $\mathrm{mL}$ Erlenmeyer flasks containing $95 \mathrm{~mL}$ of YNB broth with glucose $\left(5\right.$ g.L $\left.\mathrm{L}^{-1}\right)$ and citrus pectin $\left(5\right.$ g.L $\left.\mathrm{L}^{-1}\right)$ were inoculated with $5 \mathrm{~mL}$ of an appropriate dilution of a suspension of the microorganism $\left(\mathrm{DO}_{620}=0,96\right)$, grown in $\mathrm{YM}$ medium $\left(30^{\circ} \mathrm{C}, 24\right.$ hours). The Erlenmeyer flasks were incubated at $30^{\circ} \mathrm{C}$ for 24 hours on a rotary shaker at $180 \mathrm{rpm}$. The biomass was separated by centrifugation at $2350 \times g$, for 10 minutes at $5{ }^{\circ} \mathrm{C}$. The culture medium supernatant, named enzymatic extract (EE), was frozen at $-18{ }^{\circ} \mathrm{C}$ and used as a source of extracellular enzymes. The assay batch cultures were run in triplicate, and mean values were calculated.

\subsection{Analytical techniques}

Qualitative cup-plate assay: Petri dishes were filled with $20 \mathrm{~mL}$ of a medium composed of 10 g.L.-1 PGA (Sigma) and 15 g. $\mathrm{L}^{-1}$ agar solution in a $0.2 \mathrm{M}$ sodium acetate buffer $(\mathrm{AcB})$, $\mathrm{pH}$ 5.0. The cups (5 $\mathrm{mm}$ in diameter) were cut and filled with $45 \mu \mathrm{L}$ of the EE. The plates were incubated at $37^{\circ} \mathrm{C}$ for 48 hours. Pectolytic activity was recognized by a clear halo after the medium was flooded with $5 \mathrm{~N} \mathrm{HCl}$ (SOUZA et al., 2003).

Polygalacturonase $(P G)$ : PG activity was assayed by measuring the reducing groups released from 2 g.L. $\mathrm{L}^{-1}$ PGA (Sigma) solution in AcB (0.2 M, pH 5.0) using the dinitrosalicylic acid method (MILLER, 1959). The reaction was carried out at $37^{\circ} \mathrm{C}$ for 10 minutes. A calibration curve was made using GA (Sigma) as standard. One unit of PG was defined as the amount of enzyme that releases $1 \mu \mathrm{mol}$ of GA per minute.

Pectic substances: pectic substances released from crude enzymatic extract were determined as GA by the $m$-hydroxydiphenyl-sulfuric acid technique (BLUMENKRANTZ; ASBOE-HANSEN, 1973).

Biomass: biomass was evaluated by dry weight determinations.

Glucose: glucose was determined using the glucose oxidaseperoxidase (Glicemia, Wiener, Argentina) method.

\subsection{Maceration activity assay}

Cassava roots were purchased from a local market and used for maceration tests with EE of the pectinolytic yeast isolated. They were peeled and cut into pieces measuring 3-4 $\mathrm{mm}$ on both sides. The pieces were submerged in an enzyme 
solution in Petri dishes and incubated at $30^{\circ} \mathrm{C}$ for up to 2 hours. Maceration activity was estimated from the loss in coherence of tissue sections. As a control, blanks were prepared with heatdenatured enzymes (SCHWAN; COOPER; WHEALS, 1997).

Microscopic observations of the maceration process were also performed. Each experience was assayed in triplicate.

\section{Results and discussion}

\subsection{Isolation and identification of a pectinolytic yeast}

Among 160 yeast strains isolated from citrus peels, one exhibited the strongest pectinolytic activity when grown on YNB agar, with diameter of clearing zones around colony of $28 \mathrm{~mm}$.

The ITS1-5.8S-ITS4 amplicon obtained from the yeast isolate showed a size of $600 \mathrm{bp}$. Restriction analyses of the amplicon were obtained by three enzymes (Hinf I; Hae III, and $C f o$ I). The restriction pattern obtained was partially coincident with the profile described for Pichia anomala according to YeastId database (CSIC - Valencia University, Spain), showing similar restriction fragments with two enzymes (Hinfl and HaeIII), but an additional restriction site with the enzyme $C f o I$. Table 1 shows the 5.8-ITS experimental patterns obtained for this yeast isolate. Sequencing of ITS1-5.8S-ITS4 amplicon allowed confirming the species identification of Wickerhamomyces anomalus, the recent reclassification of Pichia anomala species (KURTZMAN; ROBNETT; BASEHOAR-POWERS, 2008).

Species assignments in the genus Pichia have been markedly affected by gene sequence analysis. This restructuring of yeast classification, however, has resulted in new genus assignments for many species, including Pichia anomala (KURTZMAN; ROBNETT, 1998). Since a taxonomy based on phylogenetic data is preferable over a more-or-less artificial system, it is clear that the current name Pichia anomala should no longer

Table 1. Nucleotide fragment length of 5.8S-ITS profile obtained from the isolated yeast.

\begin{tabular}{lcccc}
\hline \multirow{2}{*}{ Species } & AP $(\mathrm{bp})^{*}$ & \multicolumn{3}{c}{$\begin{array}{c}\text { Fragment length(s) (bp) after restriction } \\
\text { endonuclease analysis with: }\end{array}$} \\
\cline { 3 - 5 } & & CfoI & HaeII & HinfI \\
\hline Pichia & 600 & $290+260$ & 600 & $320+280$ \\
\hline${ }^{*}$ AP, 5.8S-ITS amplified product size.
\end{tabular}

be used. Thus, a new genus, Wickerhamomyces was suggested (KURTZMAN; ROBNETT; BASEHOAR-POWERS, 2008; KURTZMAN, 2011). The first International Pichia anomala Symposium provided a survey of past, recent, and ongoing research on this yeast. The current debate focuses on whether the yeast should be designated as Wickerhamomyces anomalus or if the previous name, Hansenula anomala, should be reinstated (PASSOTH; OLSTORPE; SCHNÜRER, 2011). There have been strong arguments that, according to taxonomic rules, the oldest valid name of a genus must be used. Since all teleomorphs in the new genus Wickerhamomyces earlier belonged to Hansenula, with the type species Hansenula anomala, it was suggested that the original name Hansenula should be reintroduced (NAUMOV; NAUMOVA, 2010; PASSOTH; OLSTORPE; SCHNÜRER, 2011). Problems and conflicts over the correct designation of species are not uncommon in yeast research, as seen a few years ago for the genus Saccharomyces (VAUGHANMARTINI; MARTINI, 1995).

\subsection{Production of pectinolytic enzymes in submerged fermentation}

Different substrates were tested as carbon and energy sources (CES) for the growth and PG production of $W$. anomalus in liquid medium. The results of the cultures carried out in Erlenmeyers flasks with YNB broth using different CES, at $30^{\circ} \mathrm{C}$, for 24 hours, are shown in Table 2. Pectinolytic activity of EE was evidenced by the presence of halos of hydrolysis developed on plates containing PGA (Figure 1).

Table 2 shows that the growth of $W$. anomalus in YNB broth containing GA, SUC, PGA, or pectin as sole carbon and energy sources was negligible, even when the cultures were prolonged up to 72 hours. When yeast strain was grown in YNB broth, which only contained glucose, the yeast grew but enzymatic activity was not detected in the supernatants. However, the addition of citrus pectin resulted in the production of pectic enzymes. The largest halos $(4.0 \mathrm{~cm})$ were obtained in YNB agar containing 6.7 g.L $\mathrm{L}^{-1}$ of YNB (Difco), 5 g.L $\mathrm{L}^{-1}$ of glucose and 5 g.L $\mathrm{L}^{-1}$ of pectin or PGA (Figure 1).

These results suggest the yeast $W$. anomalus was unable to assimilate GA, SUC, PGA, or citrus pectin, but it requires glucose as carbon and energy source and PGA or citrus pectin to induce the synthesis of the enzyme.

Table 2. Effect of different carbon sources on growth and PG production by W. anomalus.

\begin{tabular}{|c|c|c|c|c|c|c|}
\hline \multicolumn{5}{|c|}{ Carbon and energy source (g.L $\left.\mathrm{L}^{-1}\right)$} & \multirow{2}{*}{ Growth } & \multirow{2}{*}{$\varnothing(\mathrm{cm})$} \\
\hline GLU & GA & SUC & PGA & PEC & & \\
\hline 5.0 & - & - & - & - & Good growth & nd \\
\hline- & 5.0 & - & - & - & No growth & nd \\
\hline- & - & 5.0 & - & - & No growth & nd \\
\hline- & - & - & 5.0 & - & No growth & nd \\
\hline- & - & - & - & 5.0 & No growth & nd \\
\hline 5.0 & & & 5.0 & - & Good growth & 4.0 \\
\hline 5.0 & - & - & & 2.5 & Good growth & 2.7 \\
\hline 5.0 & & & & 5.0 & Good growth & 4.0 \\
\hline
\end{tabular}

GLU: glucose; GA: galacturonic acid; SUC: sucrose; PGA: polygalacturonic acid; PEC: pectin; Ø: diameter of the hydrolysis halo; nd: not detected. 
Several authors reported that most of the pectinolytic yeasts are unable to use pectin or its derivatives such as CES (BLANCO et al., 1994; SCHWAN; COOPER; WHEALS, 1997). Fernández-González et al. (2004) reported that several yeasts isolated from wine ecosystems were unable to grow when GA was the sole CES in YNB medium. Similarly, Masoud and Jespersen (2006) reported that certain yeast isolated during fermentation of coffee did not grow in a culture medium containing only PGA without the addition of glucose. Blanco, Sieiro and Villa (1999) reported that yeast pectinases are constitutively produced because pectin, PGA, and GA are not required to induce the synthesis of these enzymes. However, the pectinolytic capacity of some species has been described as inducible, such as: Cryptococcus albidus and Geotrichum lactis

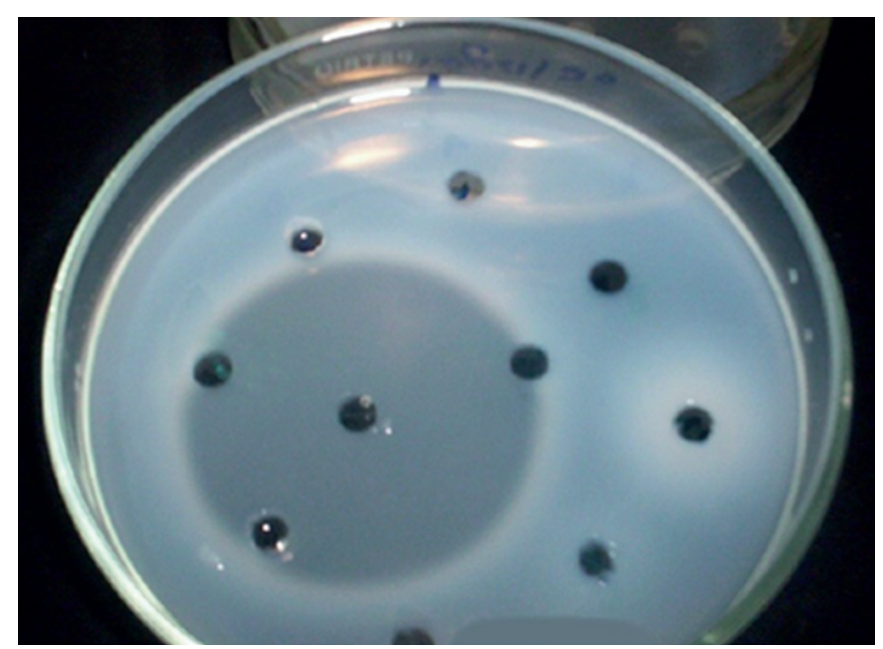

Figure 1. Hydrolysis halos on plates with polygalacturonic acid originated by the enzymatic extract of $W$. anomalus cultured in YNB broth containing glucose $\left(5\right.$ g.L $\left.\mathrm{L}^{-1}\right)$ and pectin $\left(5\right.$ g.. $\left.\mathrm{L}^{-1}\right)$.
(BLANCO; SIEIRO; VILLA, 1999), eight wine yeast strains of Saccharomyces sp. (RADOI; KISHIDA; KAWASAKI, 2005) and pectinolytic yeasts predominant during coffee processing (six strains of Pichia anomala, four strains of Pichia kluyveri, and two strains of Hanseniaspora uvarum) (MASOUD; JESPERSEN, 2006).

Figure 2 shows the time course of the culture of $W$. anomalus in YNB broth with glucose (5 g.L $\left.\mathrm{L}^{-1}\right)$ and citrus pectin ( 5 g.L $\left.\mathrm{L}^{-1}\right)$ as substrates.

Cultures carried out in Erlenmeyer flasks with YNB broth showed that the microorganism grew well in this medium (Figure 2). Glucose was exhausted when the culture reached the stationary growth phase (7 hours), when the biomass produced was $2.15 \mathrm{~g} . \mathrm{L}^{-1}$, value that led to a biomass yield $\left(\mathrm{Y}_{\mathrm{x} / \mathrm{s}}\right)$ of $0.43 \mathrm{~g}$ of cell dry weight per gram of glucose consumed. The $\mathrm{pH}$ decreased during the culture from an initial value of 5.0 up to about 3.0 at the end of the fermentation process. The maximum specific growth rate $\left(\mu_{\mathrm{m}}\right)$ of $0.346 \mathrm{~h}^{-1}\left(\mathrm{R}^{2}: 0.92\right)$ was calculated. PG synthesis appears to be associated with yeast growth, reaching. $51 \pm 0.40$ UE. $\mathrm{mL}^{-1}$ at the end of the culture. Similarly, PG synthesis by $A$. kawachii (CONTRERAS ESQUIVEL et al., 1999) and Geotrichum klebahnii (CAVALITTO; HOURS; MIGNONE, 2000) were associated with the growth phase of the microorganism. PG activity decreased during longer cultivation times probably due to inactivation by proteases produced by the microorganism (MALVESSI; SILVEIRA, 2004).

The pectic substances levels reached in the culture medium are shown in Figure 3.

Figure 3 shows that there was no significant decrease in the concentration of pectin during the fermentation process. AG values obtained in the culture medium at the beginning of the fermentation process and after 24 hours were $3381 \pm 54.95$
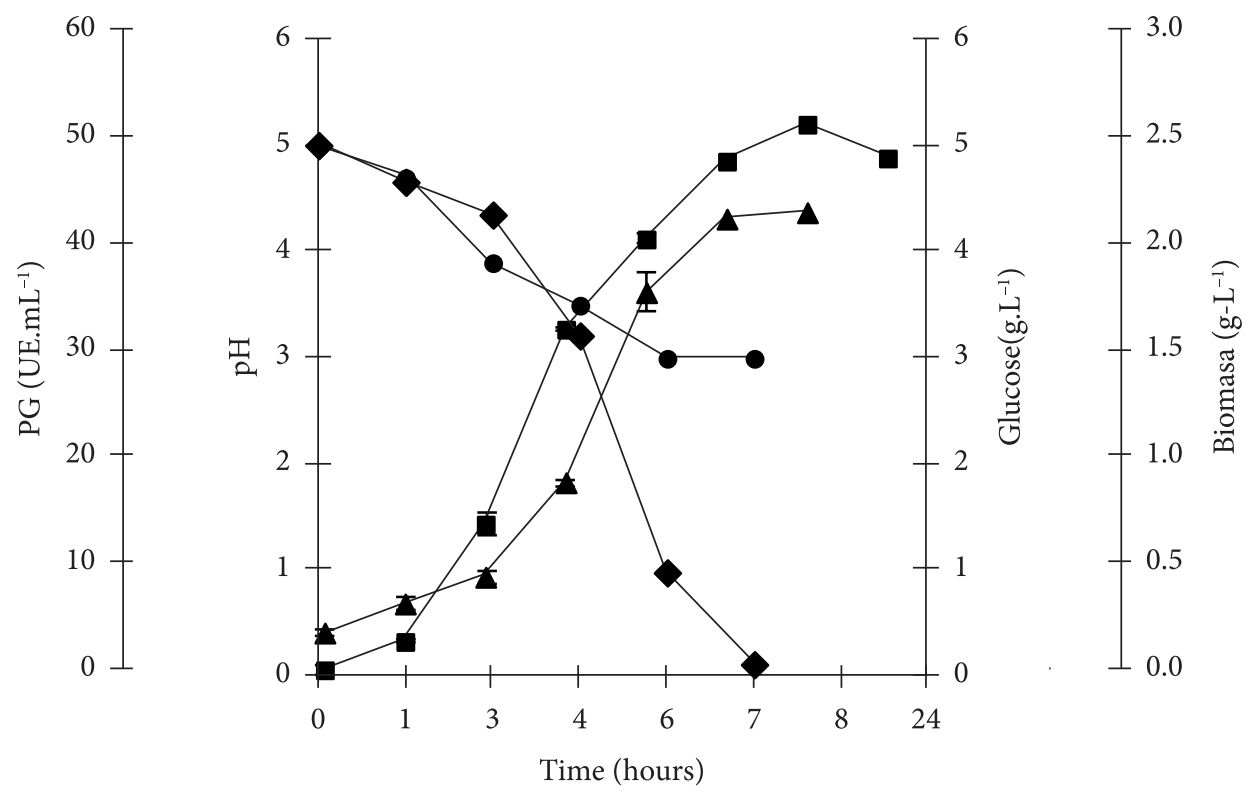

Figure 2. Time course of biomass, enzyme activity, residual glucose, and pH during the cultivation of W. anomalus in YNB broth. Symbols: PG activity $(\bullet)$, biomass $(\boldsymbol{\Delta})$, glucose $(\bullet), \mathrm{pH}(\bullet)$. 


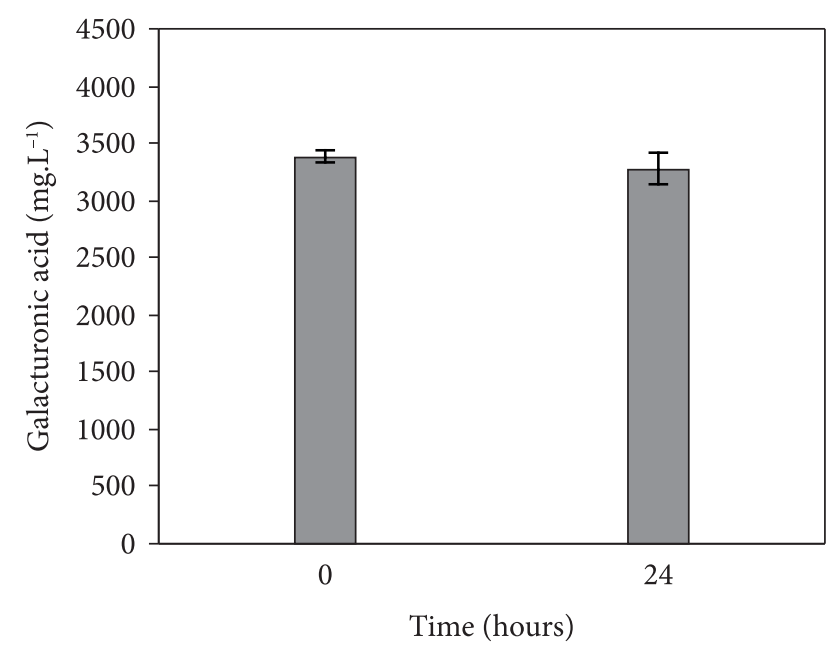

Figure 3. Pectic substances levels (determined as galacturonic acid) reached in the culture medium.

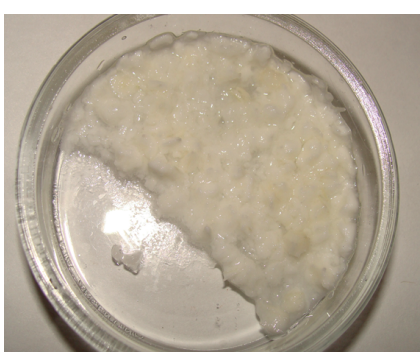

(a)

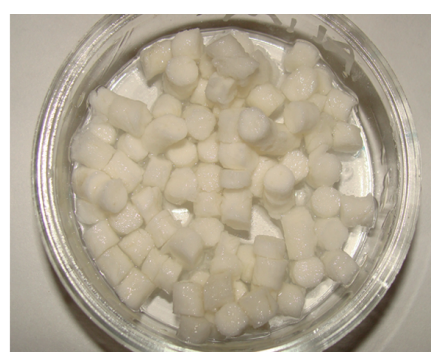

(b)
Figure 4. Cassava tissue after maceration process with enzymatic extract of $W$. anomalus (a); control (b).

and $3276 \pm 133$, respectively. Analysis of variance revealed no significant differences between these values $(\mathrm{p}<0.05)$.

In general, extracellular depolymerizing enzymes such as pectinases and, in particular, PGases share a common feature, which is glucose-repressible synthesis (CAVALITTO; HOURS; MIGNONE, 2000). This effect has been reported in Saccharomyces cerevisiae (BLANCO et al., 1994), Cryptococcus albidus (FEDERICI, 1985), and Kluyveromyces marxianus (SCHWAN; ROSE, 1994). By contrast, $W$. anomalus does not exhibit this effect, and PG seems to show inducible synthesis.

The role of PG in yeasts is largely unknown, and it is remarkable that two different types of yeasts may be discerned. One group includes yeasts that, like filamentous fungi, have the ability to growth using pectic substances such as the sole CES, suggesting a complex enzymic system, such as in the cases of Cryptococus albidus and C. boidinii (BLANCO; SIEIRO; VILLA, 1999). The other group comprises those yeasts unable to use pectin, pectate, or their hydrolysis products such as CES, and these strains mainly produce endo-PG able to degrade pectic substrates. This fact challenges the ability to investigate the real physiological role of pectolytic enzymes in this species. As far as it is known; these enzymes could be involved in substrate colonization (fruits). This causes the breakdown of plant tissues

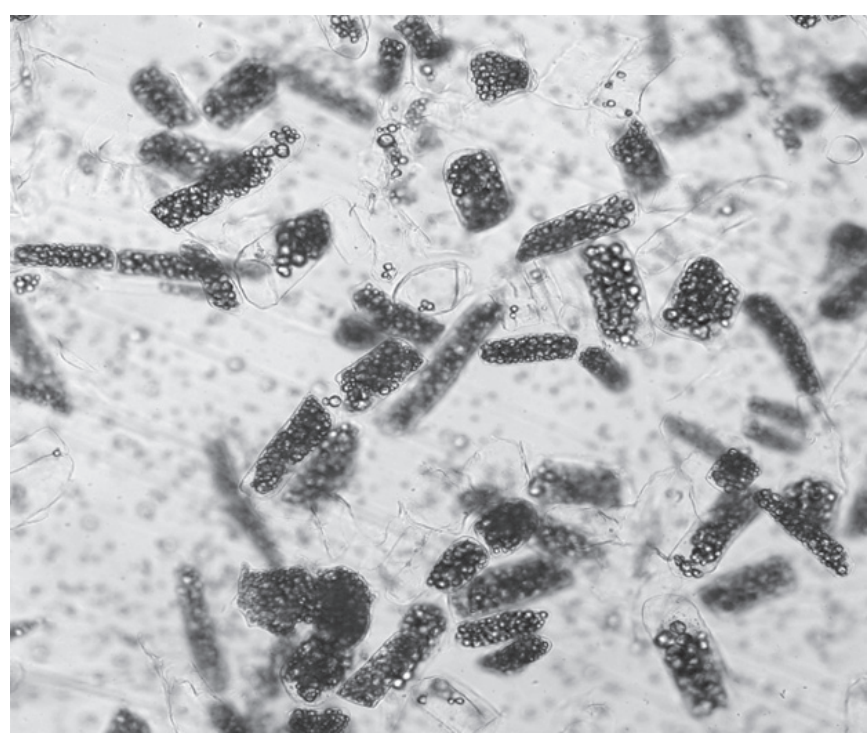

Figure 5. Photomicrographs of cassava tissue cells after maceration process with enzymatic extract of $W$. anomalus.

with the concomitant release of sugars from plant cells, which in turn can be used for yeast growth, hence causing further spoilage (DA SILVA et al., 2005). It can be concluded that $W$. anomalus may belong to the second group of yeasts.

\subsection{Assay of maceration activity}

Figures 4 and 5 show cassava tissue and photomicrographs $(400 \times)$ of released cells, respectively, after the maceration process with crude culture supernatants of $W$. anomalus.

The EE showed macerating activity; it was observed loss of coherence of tissue (Figure 4), and microscopic examination of the maceration products showed single cells (Figure 5).

$W$. anomalus produces PG with pectin releasing activity named protopectinase (PPase). The name PPase for this enzyme was kept to differentiate it from the classical PGases without pectin releasing activity (ROJAS et al., 2008). Some PPases have been reported with different pectin solubilizing activities depending on the substrate (potato, carrot, garland chrysanthemum, garlic, ginger, spinach, or red pepper) (NAKAMURA; HOURS; SAKAI, 1995). The first PPase reported was found in a culture filtrate of Geotrichum klebahnii, and it was identified as an endo-PG (endo-PG, EC 3.2.1.15). This enzyme was highly efficient for enzymatic extraction of pectin from citrus peel and for the maceration of potato tissues (CAVALITTO; HOURS; MIGNONE, 2000).

\section{Conclusions}

The wild-type yeast isolated was identified as Wickerhamomyces anomalus (Pichia anomala). The strain was able to produce PG in liquid medium containing glucose and citrus pectin. PG activity was 51 UE. $\mathrm{mL}^{-1}$ after 8 hours of fermentation. The microorganism needs glucose to grow. It was unable to assimilate GA, SUC, PGA, or PEC, but it requires 
glucose as carbon and energy source and PGA or citrus pectin to induce the synthesis of the enzyme.

W. anomalus produces PG, an extracellular enzyme, with pectin releasing activity named protopectinase. This enzyme would be responsible for the maceration of cassava tissues. This property is very important in the production of dehydrated mashed cassava, a product of regional interest in the province of Misiones, Argentina, replacing mechanical methods which produce a large cellular disruption.

\section{References}

ALTSCHUL, S. F. et al. Basic local alignment search tool. Journal of Molecular Biology, v. 215, p. 403-410, 1990. PMid:2231712.

BLANCO, P. et al. Production and partial characterization of an endopolygalacturonase from Saccharomyces cerevisiae. Canadian Journal of Microbiology, v. 40, p. 974-977, 1994. PMid:7804908. http://dx.doi.org/10.1139/m94-155

BLANCO, P.; SIEIRO, C.; VILLA, T. G. Production of pectic enzymes in yeasts. Mini Review. FEMS Microbiology Letters, v. 175, p. 1-9, 1999. PMid:10361703. http://dx.doi.org/10.1111/j.1574-6968.1999. tb13595.x

BLUMENKRANTZ, N.; ASBOE-HANSEN, G. A new method for quantitative determination of uronic acids. Analytical Biochemistry, v. 54, p. 484-489, 1973. http://dx.doi. org/10.1016/0003-2697(73)90377-1

BROUSSE, M. M. et al. Cinética de adsorción de agua en purés deshidratados de mandioca (Manihot esculenta Crantz). Revista Venezolana de Ciencia y Tecnología de Alimentos, v. 3, n. 1, p. 80-96, 2012.

CAVAliTTO, S. F.; HOURS, R. A.; MIGNONE, C. F. Growth and protopectinase production of Geotrichum klebahnii in batch and continuous cultures with synthetic media. Journal of Industrial Microbiology and Biotechnology, v. 25, p. 260-265, 2000. http:// dx.doi.org/10.1038/sj.jim.7000072

CONTRERAS ESQUIVEL, J. C. et al. Aspergillus kawachii produces an acidic pectin releasing enzyme activity. Journal of Bioscience and Bioengineering, v. 8, n. 1, p. 48-52, 1999. http://dx.doi.org/10.1016/ S1389-1723(99)80174-1

COSTA, J. A. V. et al. Simultaneous amyloglucosidase and exopolygalacturonase production by Aspergillus niger using solid-state fermentation. Brazilian Archives of Biology and Technology, v. 50, n. 5, p. 759-766, 2007. http://dx.doi.org/10.1590/S151689132007000500003

DA SILVA, E. G. et al. Pectinolytic enzymes secreted by yeasts from tropical fruits. FEMS Yeast Research, v. 5, p. 859-865, 2005. PMid:15925314. http://dx.doi.org/10.1016/j.femsyr.2005.02.006

ESTEVE ZARZOSO, B. et al. Identification of yeasts by RFLP analysis of the 5.8S rRNA gene and two ribosomal internal transcribed spacers. International Journal of Systematic Bacteriology, v. 49, p. 329337, 1999. PMid:10028278. http://dx.doi.org/10.1099/0020771349-1-329

FEDERICI, F. Production, purification and partial characterization of an endopolygalacturonase from Cryptococcus albidus var. albidus. Antonie Van Leeuwenhoek, v. 51, p. 139-150, 1985. PMid:4037779. http://dx.doi.org/10.1007/BF02310007

FERNÁNDEZ-GONZÁLEZ, M. et al. Evaluation of polygalacturonase activity in Saccharomyces cerevisiae wine strains. FEMS Microbiology Letters, v. 237, p. 261-266, 2004. PMid:15321671. http://dx.doi.org/10.1111/j.1574-6968.2004.tb09705.x
GRANCHI, L. et al. Rapid detection and quantification of yeast species during spontaneous wine fermentation by PCR-RFLP analysis of the rRNA ITS region. Journal of Applied Microbiology, v. 87, p. 949-956, 1999. PMid:10692077. http://dx.doi.org/10.1046/j.13652672.1999.00600.x

HOFFMAN, C. S.; WINSTON, F. A ten-minute DNA preparation from yeast efficiently release autonomous plasmids for transformation of E. coli. Gene, v. 57, p. 267-272, 1987. http://dx.doi.org/10.1016/03781119(87)90131-4

JAYANI, R. S.; SAXENA, S.; GUPTA, R. Microbial pectinolytic enzymes: A review. Process Biochemistry, v. 40, p. 2931-2944, 2005. http://dx.doi.org/10.1016/j.procbio.2005.03.026

KURTZMAN, C. P. Phylogeny of the ascomycetous yeasts and the renaming of Pichia anomala to Wickerhamomyces anomalus. Antonie Van Leeuwenhoek, v. 99, p. 13-23, 2011. PMid:20838888. http://dx.doi.org/10.1007/s10482-010-9505-6

KURTZMAN, C. P.; ROBNETT, C. J. Identification and phylogeny of ascomycetous yeasts from analysis of nuclear large subunit (26S) ribosomal DNA partial sequences. Antonie Van Leeuwenhoek, v. 73, p. 331-371, 1998. PMid:9850420. http:// dx.doi.org/10.1023/A:1001761008817

KURTZMAN, C. P.; ROBNETT, C. J.; BASEHOAR-POWERS, E. Relationships among species of Pichia, Issatchenkia and Williopsis determined from multigene phylogenetic analysis and the proposal of Barnettozyma gen. nov., Lindnera gen. nov. and Wickerhamomyces gen. nov. FEMS Yeast Research, v. 8, p. 939954, 2008. PMid:18671746. http://dx.doi.org/10.1111/j.15671364.2008.00419.x

MALVESSI, E.; SILVEIRA, M. M. Influence of medium composition and $\mathrm{pH}$ on the production of polygalacturonases by Aspergillus oryzae. Brazilian Archives of Biology and Technology, v. 47, p. 693-702, 2004. http://dx.doi.org/10.1590/S151689132004000500004

MASOUD, W.; JESPERSEN, L. Pectin degrading enzymes in yeasts involved in fermentation of Coffea arabica in East Africa. International Journal of Food Microbiology, v. 110, p. 291-296, 2006. PMid:16784790. http://dx.doi.org/10.1016/j. ijfoodmicro.2006.04.030

MILLER, G. L. Use of dinitrosalicylic acid reagent for determination of reducing sugar. Analytical Chemistry, v. 31, p. 426-428, 1959. http://dx.doi.org/10.1021/ac60147a030

NAKAMURA, T.; HOURS, R. A.; SAKAI, T. Enzymatic maceration of vegetables with protopectinases. Journal of Food Science, v. 60, p. 468-472, 1995. http://dx.doi.org/10.1111/j.1365-2621.1995. tb09805.x

NAUMOV, G. I.; NAUMOVA, E. S. Taxonomy and genetics of the yeast Pichia/Hansenula anomala. In: PICHIA ANOMALA MINI-SYMPOSIUM, 1., 2010, Uppsala, Sweden. Proceedings... Uppsala, 2010.

PASSOTH, V.; OLSTORPE, M.; SCHNÜRER, J. Past, present and future research directions with Pichia anomala. Antonie Van Leeuwenhoek, v. 99, p. 121-125, 2011. PMid:20924674. http:// dx.doi.org/10.1007/s10482-010-9508-3

RADOI, F.; KISHIDA, M.; KAWASAKI, H. Endo-polygalacturonase in Saccharomyces wine yeasts: effect of carbon source on enzyme production. FEMS Yeast Research, v. 5, p. 663-668, 2005. PMid:15780666. http://dx.doi.org/10.1016/j.femsyr.2004.09.006

ROJAS, N. L. et al. Role of PPase-SE in Geotrichum klebahnii, a yeast-like fungus able to solubilize pectin. Electronic Journal Biotechnology, v. 1, n. 1, p. 1-8, 2008. 
SCHWAN, R. F.; COOPER, R. M.; WHEALS, A. E. Endopolygalacturonase secretion by Kluyveromyces marxianus and other cocoa pulp-degrading yeasts. Enzyme and Microbial Technology, v. 21, p. 234-244, 1997. http://dx.doi.org/10.1016/ S0141-0229(96)00261-X

SCHWAN, R. F.; ROSE, A. H. Polygalacturonase production by Kluyveromyces marxianus: effect of medium composition. Journal of Applied Bacteriology, v. 76, p. 62-67. 1994. http://dx.doi. org/10.1111/j.1365-2672.1994.tb04416.x

SOUZA, J. V. B. et al. Screening of fungal strains for pectinolytic activity: endopolygalacturonase production by Peacilomyces clavisporus $2 \mathrm{~A}$. UMIDA.1. Process Biochemistry, v. 39, p. 455-458, 2003. http:// dx.doi.org/10.1016/S0032-9592(03)00092-X
TARI, C.; GÖGUS, N.; TOKATLI, F. Optimization of biomass, pellet size and polygalacturonase production by Aspergillus sojae ATCC 20235 using response surface methodology. Enzyme and Microbial Technology, v. 40, p. 1108-1116, 2007. http://dx.doi. org/10.1016/j.enzmictec.2006.08.016

VAUGHAN-MARTINI, A.; MARTINI, A. Facts, myths and legends on the prime industrial microorganism. Journal of Industrial Microbiology, v. 14, p. 514-522, 1995. PMid:7662293. http://dx.doi. org/10.1007/BF01573967

WHITE, T. et al. Amplification and direct sequencing of fungi ribosomal RNA genes for phylogenetics. In: INNIS, M. et al. (Eds.). PCR Protocols: A guide to methods and applications. San Diego: Academic Press; 1990. 